\title{
Leaching Behavior of Cadmium through Compacted Granitic Residual Soil Using Column Infiltration Test
}

\author{
Nur 'Aishah Zarime* and Wan Zuhairi Wan Yaacob \\ Geology Programme, Faculty of Science and Technology, Universiti Kebangsaan Malaysia, Malaysia
}

\begin{abstract}
This study investigates the physico-chemical properties of granitic residual soils and comparison between two sorption tests; batch and column infiltration tests in evaluating the mobility of Cadmium $(\mathrm{Cd})$ using granitic residual soils. The granitic residual soil has undergone the physical tests (eg: particle size distribution, Atterberg Limits, specific gravity and compaction), chemical tests (eg: pH, organic matter, specific surface area (SSA) and cation exchange capacity (CEC)) and sorption tests. For Batch test, the effect of $\mathrm{Cd}$ concentration in single and mixture solutions were studied. The result showed the $\mathrm{K}_{\mathrm{d}}$ value of single solution $\left(\mathrm{K}_{\mathrm{d}}=0.0062 \mathrm{~L} / \mathrm{g}\right)$ was higher compared to mix solution $\left(\mathrm{K}_{\mathrm{d}}=0.0022 \mathrm{~L} / \mathrm{g}\right)$. For column infiltration test, several factors were studied in this research such as different g-force, different types of solutions and different soil thickness. Results showed that both sorption tests have different effects on mobility of heavy metals through soils. The column infiltration test gave the exact $\mathrm{K}_{\mathrm{d}}$ values compared to the batch test since the condition of columns method applied were similar to the natural soil conditions.
\end{abstract}

\section{Introduction}

Human activities such as agricultural, domestic waste, municipal sewage, industrial effluent, mining activities, and landfill introduced the contaminant/ heavy metals to our natural environment [1], [2], [3]. Adsorption is one of the most common method to remove heavy metals due to its low cost and efficient absorbents [4]. According to [5] and [6], column leaching techniques was widely used to evaluate the transport model and determined the migration of contaminant through soils. The objectives of this study are to investigate the chemical-physical properties of granitic residual soils and to compare the batch and column techniques in evaluating the mobility of Cadmium (Cd) through granitic residual soil.

\section{Materials and Method}

Granitic residual soil was collected from Broga, Selangor, Malaysia. Sample was air-dried and sieved less than $0.125 \mathrm{~mm}$. Physico-chemical tests were analyzed according to [7]. Batch test and column infiltration tests were conducted according to [8], [9] methods; respectively.

\section{Results and Discussions}

\subsection{Physico-Chemical Characteristics}

The physical and chemical characteristic of the soil were presented in Table 1 and Table 2. Granitic residual soil has higher percentage of sand ranged between 54\%-63\% followed by percentage of silt $(32 \%-42 \%)$ and clay (1\%-6\%). Due to this, granitic residual soil has classified as intermediate plasticity index (9.90\%-11.99\%). According to [10], low plasticity index indicates lower adsorption capacity. Granitic residual soil showed low $\mathrm{pH}$ value (acidic) ranged between 5.35-5.85. In acidic conditions, heavy metals were mobile and adsorption of heavy metals onto soils became less effective [11]. This study also showed the soil has low values of organic matter $(0.22 \%-0.34 \%)$, SSA $\left(17.96 \mathrm{~m}^{2} / \mathrm{g}-21.93 \mathrm{~m}^{2} / \mathrm{g}\right)$ and CEC $(0.79 \mathrm{meq} / 100 \mathrm{~g}-1.35 \mathrm{meq} / 100 \mathrm{~g})$ where it indicates low adsorption capacity.

\subsection{Sorption Test}

In this sorption test, Batch test and Column Infiltration test were chosen to obtain partition coefficient $\left(\mathrm{K}_{\mathrm{d}}\right) . \mathrm{K}_{\mathrm{d}}$ can be defined as the amount of contaminant adsorbed in the soil solid phase to the metal concentration in the soil solution, at equilibrium [12]. The $K_{d}$ values in all parameters calculated from the column and batch test were presented in Table 3.

\footnotetext{
* Corresponding author: aishahzarime @ gmail.com
} 


\subsubsection{Batch Test}

The partition coefficient $\left(\mathrm{K}_{\mathrm{d}}\right)$ of $\mathrm{Cd}$ in single and mixture solutions is summarized in Table $2 . \mathrm{K}_{\mathrm{d}}$ value of single solution $\left(\mathrm{K}_{\mathrm{d}}=0.0062 \mathrm{~L} / \mathrm{g}\right)$ was higher compared to mix solution $\left(\mathrm{K}_{\mathrm{d}}=0.0022 \mathrm{~L} / \mathrm{g}\right)$. $\mathrm{Cd}$ in mixture solution needs to compete with other metals in order to obtain active sites in soils. Thus, the amount of heavy metal reduced and subsequently lowering the $K_{d}$ value [13]

Table 1. Physical Characteristics of granitic residual soil

\begin{tabular}{ll}
\hline Physical Characteristics & BGR \\
\hline Particle size distribution: & $54-63$ \\
Sand (\%) & $32-42$ \\
Silt (\%) & $1-6$ \\
Clay (\%) & \\
& \\
Atterberg Limit: & $38.01-38.69$ \\
Plastic Limit (\%) & $48.50-50.00$ \\
Liquid Limit (\%) & $9.90-11.99$ \\
Plasticity Index (\%) & \\
& $2.50-2.59$ \\
Specific Gravity & $1.64-1.71$ \\
Max Dry Density $\left(\mathrm{g} / \mathrm{cm}^{3}\right)$ & \\
\hline
\end{tabular}

Table 2. Chemical Characteristics of granitic residual soil

\begin{tabular}{lc} 
Chemical Characteristics & BGR \\
\hline $\mathrm{pH}$ & $5.32-5.54$ \\
Organic Matter $(\%)$ & $0.39-0.50$ \\
SSA $(\%)$ & $17.96-21.93$ \\
CEC (meq/100g) & $0.79-1.35$ \\
\hline SSA: Specific Surface Area; CEC: Cation Exchange Capacity
\end{tabular}

\subsubsection{Column Infiltration Test}

\section{i. $\quad K_{d}$ in Different G-Forces}

The calculated $K_{d}$ values showed the $K_{d}$ values reduced when G-force were increased. At higher G-force, the contact between heavy metals and soil particle was limited, thus reduced the sorption and $K_{d}$ values. However, there was overestimated $\mathrm{K}_{\mathrm{d}}$ values due to the non-homogeneous particle size distribution and uneven compaction process of the soils. The overestimated $\mathrm{K}_{\mathrm{d}}$ values can be seen at $10 \mathrm{~mm}$ soil thickness and $520 \mathrm{G}$ in a single solution, where the $\mathrm{K}_{\mathrm{d}}$ value showed $23.449 \mathrm{~L} / \mathrm{kg}$.

\section{ii. $\quad K_{d}$ in Different Types of Solutions}

In $10 \mathrm{~mm}$ of soil thickness, the comparison between $K_{d}$ values of single and mixture solution was determined. $K_{d}$ in single solutions was higher compared to mixture solution due to no competition in single solution. Thus, Kd values increased.

\section{iii. $\quad K_{d}$ in Different Soil Thickness}

In this study, the $K_{d}$ values in $520 \mathrm{G}$ of all soil thickness showed the decreasing values of $K_{d}$ with increasing of soil thickness $(10 \mathrm{~mm}=23.449 \mathrm{~L} / \mathrm{kg}$, $15 \mathrm{~mm}=0.648 \mathrm{~L} / \mathrm{kg}, 20 \mathrm{~mm}=0.109 \mathrm{~L} / \mathrm{kg}$ ). The flow rate of contaminant in clay liner will decrease with increasing of soil thickness. Thus, the active site also decreased, subsequently lowering the adsorption and $\mathrm{K}_{\mathrm{d}}$ values.

\section{iv. $\quad K_{d}$ in Column Test versus Batch Test}

For both single and mixture solutions, $\mathrm{K}_{\mathrm{d}}$ in batch test showed higher values (single solution, $\mathrm{K}_{\mathrm{d}}=$ $6.2 \mathrm{~L} / \mathrm{kg}$ and mixture solution, $\mathrm{K}_{\mathrm{d}}=2.2 \mathrm{~L} / \mathrm{kg}$ ) compared to all $\mathrm{K}_{\mathrm{d}}$ values in column infiltration test. In Batch test, the adsorption of contaminants was in 'closed system' where secondary reaction such as precipitation may occur. In this case, the concentration of contaminants in equilibrium concentration reduced and caused the increasing of $K_{d}$ values [9]. However, $K_{d}$ value for mini column infiltration test (G-force; $520 \mathrm{~g}$ in single solution) showed a higher value $\left(\mathrm{K}_{\mathrm{d}}=23.449 \mathrm{~L} / \mathrm{kg}\right)$ compared to $\mathrm{K}_{\mathrm{d}}$ for batch test $\left(\mathrm{K}_{\mathrm{d}}=6.2 \mathrm{~L} / \mathrm{kg}\right)$. This overestimated value was due to the nonhomogeneous particle size distribution and uneven compaction process of the soils. 
Table 3. $K_{d}$ value in all parameters calculated from the column and batch test.

\begin{tabular}{|c|c|c|c|c|c|c|c|}
\hline \multicolumn{4}{|c|}{ Column Infiltration Test } & \multicolumn{4}{|c|}{ Batch Test } \\
\hline \multirow{2}{*}{$\begin{array}{l}\text { Weight } \\
\text { (g)/ } \\
\text { Thickness } \\
(\mathrm{mm})\end{array}$} & \multirow{2}{*}{$\begin{array}{l}\text { Velocity } \\
\text { (RPM)/ } \\
\text { G-Force }\end{array}$} & \multirow{2}{*}{$\begin{array}{c}\text { Kd in Single } \\
\text { Solution L/kg }\end{array}$} & \multirow{2}{*}{$\begin{array}{l}\mathrm{K}_{\mathrm{d}} \text { in Mixture } \\
\text { Solution } \mathrm{L} / \mathrm{kg}\end{array}$} & \multicolumn{2}{|c|}{ Single Solution } & \multicolumn{2}{|c|}{ Mixture Solution } \\
\hline & & & & $\begin{array}{c}\mathrm{K}_{\mathrm{d}} \\
(\mathrm{L} / \mathrm{kg})\end{array}$ & $\mathrm{R}^{2}$ & $\mathrm{~K}_{\mathrm{d}}(\mathrm{L} / \mathrm{kg})$ & $\mathrm{R}^{2}$ \\
\hline \multirow[t]{4}{*}{10} & $1000 / 230 \mathrm{G}$ & 0.514 & 0.777 & \multirow{12}{*}{6.2} & \multirow{12}{*}{0.913} & \multirow{12}{*}{2.2} & \multirow{12}{*}{0.838} \\
\hline & $1500 / 520 \mathrm{G}$ & 23.449 & 1.079 & & & & \\
\hline & 2000/ 920G & 0.793 & 0.420 & & & & \\
\hline & $2500 / 1440 \mathrm{G}$ & 0.981 & 0.417 & & & & \\
\hline \multirow[t]{4}{*}{15} & $1000 / 230 \mathrm{G}$ & 0.668 & - & & & & \\
\hline & $1500 / 520 \mathrm{G}$ & 0.648 & - & & & & \\
\hline & 2000/ 920G & 0.811 & - & & & & \\
\hline & $2500 / 1440 \mathrm{G}$ & 0.473 & - & & & & \\
\hline \multirow[t]{4}{*}{20} & $1000 / 230 \mathrm{G}$ & 3.840 & - & & & & \\
\hline & $1500 / 520 \mathrm{G}$ & 0.109 & - & & & & \\
\hline & 2000/ 920G & 0.562 & - & & & & \\
\hline & $2500 / 1440 \mathrm{G}$ & 1.448 & - & & & & \\
\hline
\end{tabular}

\section{Conclusions}

This study concludes that physico-chemical properties have a great influence in sorption and migration of $\mathrm{Cd}$ in soils. Through $\mathrm{K}_{\mathrm{d}}$ values, the comparison of both batch test and column infiltration test on mobility of $\mathrm{Cd}$ through soils can be determined. Batch test occurred in a 'closed system' where secondary reaction such as precipitation thus the concentration of contaminants in equilibrium concentration reduced and caused the increasing of $K_{d}$ values. While the column infiltration occurred in 'open system' where no interference occurred. The adsorption was continuously leached out from the system as similar to the natural conditions.

\section{Acknowledgment}

This research project was supported by Fundamental Research Grant Scheme, Project No: FRGS/1/2012/STWN06/UKM/02/2. Authors acknowledged Geology Program, Faculty of Science and Technology, Universiti Kebangsaan Malaysia (UKM), Malaysia for their assistance in conducting this research and paper.

\section{References}

1. Vega F A, Covelo E F and Andrade M L $2006 J$. Colloid Interface Sci 298 582-592

2. Kwon J, Yun S, Lee J, Kim S and Young H 2010 Journal of Hazardous Materials 174 307-313,
3. Liew C Y and Zuhairi W Y W 2010 The Adsorption of Lead, Copper, Zinc, Cadmium, Cobalt and Nickel in Residual Soils Using Batch and High Speed Centrifuge Mini Column Test Seminar UKM-UNRI Ke-6 "Penyelidikan Terkehadapan Sains dan Teknologi UKM-UNRI" 463-465

4. Lukman S, Essa M, Nuhu D M, Bukhari A, and Basheer C 2013 Journal of Environmental Science and Technology 1 1-15

5. Seaman J C, Vulava V M, Sowder A G, Jackson B P, Aburime S A, and Bertsch P M 2005 Environmental Geoscience 4 235-242

6. Masipan T, Chotpantarat S, and Boonkaewwan S 2016 Sustainable Environment Research 26 97101

7. British Standard Institution, BS1377 1990 Method of Test for Soils for Civil Engineering Purpose Part 1

8. USEPA 1992 Batch-Type Procedures for Estimating Soil Adsorption of Chemicals, EPA/530/SW- 87/006-F

9. Antoniadis V, Mckinley J D, and Zuhairi W Y W 2007 Journal of Environmental Quality 60 53-60

10. Zulfahmi A R, Umar H, and Noorulakma A 2011 Sains Malaysiana 40 293-300

11. Ouhadi V R, Yong R N, Shariatmadari N, Saeidijam S, Goodarzi A R and Safari-zanjani M 2010 Journal of Hazardous Materials 173 87-94

12. Vidal M, Santos M J, Abrão T, Rodríguez J and Rigol A 2009 Geoderma 149 189-198

13. Zarime N A and Zuhairi W Y W 2016 Sains Malaysiana 45 pp. 1905-1912 